\title{
Effects of gossypol on apoptosis-related gene expression in racially distinct triple-negative breast cancer cells
}

\author{
SAMIA S. MESSEHA, NAJLA O. ZARMOUH, PATRICIA MENDONCA, \\ HAYFAA ALWAGDANI, CAROLYN COTTON and KARAM F.A. SOLIMAN \\ College of Pharmacy and Pharmaceutical Science, Florida A\&M University, Tallahassee, Florida 32307, USA
}

Received December 24, 2018; Accepted April 12, 2019

DOI: 10.3892/or.2019.7179

\begin{abstract}
Apoptosis is a gene-directed mechanism that regulates cell proliferation and maintains homeostasis. Moreover, an aberrant apoptotic process can lead to several pathological conditions, such as tumorigenesis and cancer metastasis. In the present study, the apoptotic effect of the natural polyphenol compound gossypol (GOSS) was investigated in triple-negative breast cancer (TNBC) cells. The effect of GOSS was evaluated in two cell lines representative of a Caucasian-American and African-American origin, MDA-MB-231 (MM-231) and MDA-MB-468 (MM-468), respectively. A similar response to both cytotoxicity and proliferation was observed in the two cell lines. However, MM-468 cells were 2-fold more sensitive to the apoptotic effect of the compound, which was accompanied by a longer delay in colony formation. Furthermore, GOSS was found to alter the mRNA expression of many apoptosis-related genes. The compound significantly upregulated growth arrest and DNA damage-inducible 45 alpha protein (GADD45A), tumor necrosis factor receptor superfamily 9 (TNFRSF9) and BCL2 interacting protein 3 (BNIP3) in MM-231 cells. Similarly, GADD45A and BNIP3 were upregulated in MM-468 cells. A significant finding in this study is the profound 159-fold increase in $T N F$ gene expression that was observed in MM-468 cells. Moreover, the apoptosis-suppressor gene baculoviral IAP repeat containing 5 (BIRC5) was significantly repressed (by more than 90\%) in both cell lines, as well as death-associated protein kinase 1 (DAPK1) in MM-231 cells and tumor protein 73 (TP73) in MM-468 cells. In conclusion, the data obtained in this study provide a molecular understanding of the GOSS-induced apoptosis effect and suggest the importance of this polyphenol compound targeted towards TNBC treatment, particularly in African-American women.
\end{abstract}

Correspondence to: Dr Karam F.A. Soliman, Division of Basic Pharmaceutical Sciences, College of Pharmacy and Pharmaceutical Sciences, Florida A\&M University, 104 Dyson Pharmacy Building, 1520 S. Martin Luther King Boulevard, Tallahassee, FL 32307-3102, USA

E-mail:karam.soliman@famu.edu

Key words: gossypol, breast cancer, gene expression, apoptosis

\section{Introduction}

In normal cells, apoptosis is a genetically controlled process involving several pathways regulating development and maintaining homeostasis $(1,2)$. Defects in apoptotic pathways can lead to pathological conditions such as malignancy, metastasis and chemotherapy resistance (3). Apoptosis is mediated by two basic pathways: Extrinsic (death receptor-mediated) and intrinsic (mitochondrial or Bcl-2-regulated). Initiation of the extrinsic apoptotic pathway requires the interaction of ligands such as tumor necrosis factor $\alpha(T N F-\alpha)$ and fatty acid synthase (FAS) with their transmembrane receptors $(4,5)$. In particular, the intrinsic pathway maintains the balance between antiapoptotic and proapoptotic proteins (6). To resist apoptosis, cancer cells either upregulate the expression of antiapoptotic proteins such as Bcl-2 and Bcl-xL or downregulate the expression of proapoptotic proteins such as Bax and Bak, and both proteins are regulated by the p53 tumor-suppressor gene (7). Moreover, in an aggressive malignant phenotype, the overexpressed Bcl-2 protein prevents the release of cytochrome $c$ from the mitochondrial membrane, which leads to interruption of the intrinsic apoptotic signaling pathway and prevents apoptotic cell death (8). Similarly, in many types of cancer, the overexpression of inhibitor of apoptosis (IAP) family members is a challenge in chemoresistance (9) and is considered a therapeutic target in apoptosis-inducing strategies (10).

Breast cancer (BC) is the most commonly diagnosed cancer and the second leading cause of death among women in the United States (11). BC is commonly classified according to the gene expression profile, and the triple-negative breast cancer (TNBC) subgroup is the most aggressive and metastatic, representing approximately $10-15 \%$ of all BC cases (12). TNBC is known to be more common among African-American (AA) patients than Caucasian American (CA) patients (2). Indeed, TNBC treatment options are limited because of the absence of the three characteristic receptors: Estrogen (ER), progesterone (PR) and human epidermal growth factor $(\mathrm{Her} 2 / \mathrm{neu})(13,14)$. Although TNBC has initial higher response rates to a variety of chemotherapy agents (15), approximately $30 \%$ of patients present with a poor prognosis, and treatment failure leads to a median survival of 1 year (16).

Many studies have demonstrated the medicinal importance of the polyphenol compound gossypol (GOSS), a minor 
constituent of cotton (Gossypium hirsutum L.) seeds (17-19). GOSS has been used in China as a male contraceptive, as well as for treating malaria and viral infections $(20,21)$. GOSS has been suggested to be a potent anticancer agent against BC (22). Indeed, the antiproliferative and anti-metastatic effects of GOSS have been demonstrated in several human cancers, including leukemia (23), glioma (24), colon (25), prostate (26), adrenal (27) and breast cancer (28-30). The antiproliferative effect of GOSS is mediated through the induction of cellular apoptosis (31). Furthermore, the apoptotic effect of the compound was detected in different human cells, including multiple myeloma $(32,33)$, synovial sarcoma (34) pharynx, tongue and salivary gland (35), prostate (36-38), colon (39), ovarian $(40,41)$ gastric $(42)$, leukemia $(43,44)$ and pituitary $(45)$, in addition to breast $(31,46)$. In cancer therapy, the combination of multiple agents is key to overcoming the resistance mechanisms of the tumor (47), and GOSS has been found to induce an apoptotic effect in various human cancer cells in combination with low doses of taxanes (46), doxorubicin (34), dexamethasone (43) and valproic acid (36).

Therefore, the present study was designed to examine the effect of the natural compound GOSS on two human TNBC cell lines, MDA-MB-231 (MM-231) and MDA-MB-468 (MM-468), representing the CA and AA races, respectively (48). In the present study, we investigated the effect of GOSS on cell viability, proliferation and colony formation. We hypothesized that GOSS alters the expression of different apoptosis-related genes that mediate the antiproliferative effect of GOSS. The present study enhanced our understanding of events associated with cell death following GOSS treatment.

\section{Materials and methods}

Materials and reagents. GOSS (purity $\geq 90 \%$ ), doxorubicin (purity $\geq 99 \%$ ), and cell culture flasks were purchased from Santa Cruz Biotechnology, Inc. (Dallas, TX, USA). Trypsin-EDTA solution and Alamar Blue ${ }^{\circledR}$ (a solution of resazurin fluorescence dye) were purchased from Sigma-Aldrich (St. Louis, MO, USA). Dimethyl sulfoxide (DMSO), penicillin/streptomycin and Dulbecco's phosphate-buffered saline (DPBS) were obtained from the American Type Culture Collection (ATCC; Manassas, VA, USA). Dulbecco's modified Eagle's medium (DMEM), heat-inactivated fetal bovine serum (FBS), and cell culture plates were purchased from VWR International (Radnor, PA, USA). An Annexin V-FITC Apoptosis Detection Kit Plus (cat. no. 68FT-Ann VP-S) was purchased from RayBiotech (Norcross, GA, USA). A DNA-free ${ }^{\mathrm{TM}}$ kit (cat. no. AM1907) was purchased from Life Technologies, Inc. (Thermo Fisher Scientific, Inc., Waltham, MA, USA). An iScript ${ }^{\mathrm{TM}}$ cDNA Synthesis kit (cat. no. 170-8890), SsoAdvanced ${ }^{\mathrm{TM}}$ Universal SYBR ${ }^{\circledR}$ Green Supermix and the Human Apoptosis PCR array (SAB Target List) H96 were purchased from Bio-Rad Laboratories (Hercules, CA, USA).

Cell culture. Two TNBC cell models, MM-231 and MM-468, were purchased from the American Type Culture Collection (ATCC). Both cell lines were grown in $75-\mathrm{ml}$ tissue culture (TC) flasks at $37^{\circ} \mathrm{C}$ in a humidified $5 \% \mathrm{CO}_{2}$ incubator and subcultured as needed with trypsin/EDTA $(0.25 \%)$. The DMEM contained $4 \mathrm{mM} \mathrm{L}$-glutamine and was supplemented with $10 \%$ heat-inactivated FBS (v/v) and $1 \%$ penicillin/streptomycin salt solution $(100 \mathrm{U} / \mathrm{ml}$ and $0.1 \mathrm{mg} / \mathrm{ml}$, respectively). The DMEM was supplemented with $2.5 \%$ heat-inactivated FBS.

Cell viability assay. In this study, cells were plated at a density of $5 \times 10^{4}$ cells/well in 96-well plates and incubated overnight at $37^{\circ} \mathrm{C}$. GOSS was solubilized in dimethyl sulfoxide (DMSO), and both types of cells were treated for $24 \mathrm{~h}$ with the compound (concentration ranges of $0-100 \mu \mathrm{M}$ in MM-231 cells and 0-50 $\mu \mathrm{M}$ in MM-468 cells). Control wells were treated with DMSO at the highest concentration used $(<0.1 \%)$, and wells treated in the same manner but without cells were used as blanks. In this study, Alamar Blue ${ }^{\circledR}$ was used to determine the cell viability as previously described (49). The fluorescent fuchsia-reduced resazurin dye was measured at an excitation/emission wavelength of 530/590 nm using a Synergy HTX Multi-Mode microplate reader (BioTek Instruments, Inc., Winooski, VT, USA).

Cell proliferation and clonogenic assays. The inhibition of cell proliferation by GOSS was determined for MM-231 and MM-468 TNBC cells based on the dose-response viability study concentrations (50) using Alamar Blue ${ }^{\circledR}$. Briefly, cells were plated at an initial density of $1 \times 10^{4}$ cells/well in 96-well plates and incubated overnight at $37^{\circ} \mathrm{C}$. The cells were treated for $96 \mathrm{~h}$ with GOSS at concentrations ranging from 0 to $100 \mu \mathrm{M}$ in MM-231 cells and from 0 to $50 \mu \mathrm{M}$ in MM-468 cells in a final volume of $200 \mu \mathrm{l} /$ well. Control cells were exposed to DMSO at a concentration of $<0.1 \%$, and equivalent wells without cells were used as a blank. Doxorubicin was used as a positive control at concentrations ranging from 0 to $10 \mu \mathrm{M}$ in both cell lines. Proliferation was measured at different intervals up to $96 \mathrm{~h}$ for GOSS-treated cells and at $72 \mathrm{~h}$ for doxorubicin-treated cells (51) by adding Alamar Blue $^{\circledR}$ as previously described (49). The plates were read at an excitation/emission wavelength of 530/590 nm.

A clonogenic assay was performed to measure the long-term effect of GOSS on MM-231 and MM-468 TNBC cells. Both cell lines were seeded and treated similarly to the proliferation study described above. After either a 1- or a 6-h exposure period, the GOSS-containing experimental media were replaced by growth media after washing the cells with DPBS. The cells were allowed to grow for 7 days, and the colonies formed in both treated and untreated cells were then evaluated based on the reduction of Alamar Blue ${ }^{\circledR}$ as previously described in the Cell viability assay.

Apoptosis assay. The apoptotic effect of GOSS was determined in MM-231 and MM-468 cells. Briefly, each cell line was seeded at an initial concentration of $5 \times 10^{5}$ cells/well in 6-well plates and incubated overnight at $37^{\circ} \mathrm{C}$. To induce apoptosis, cells were treated for $24 \mathrm{~h}$ with GOSS at concentrations ranging from 0 to 100 and from 0 to $50 \mu \mathrm{M}$ in MM-231 and MM-468 cells, respectively, in a final volume of $3 \mathrm{ml} /$ well of experimental media. Control cells were exposed to DMSO at a concentration of $<0.1 \%$. After the 24-h incubation period, treated and control cells from each well were harvested, pelleted and washed in phosphate-buffered saline (PBS). According to the manufacturer's protocol, the cell pellets were resuspended in $500 \mu \mathrm{l}$ of the provided $1 \mathrm{X}$ Annexin $\mathrm{V}$ binding buffer and labeled with $5 \mu \mathrm{l}$ each of Annexin V-FITC and propidium iodide (PI). The apoptotic 
A MM-231 cells

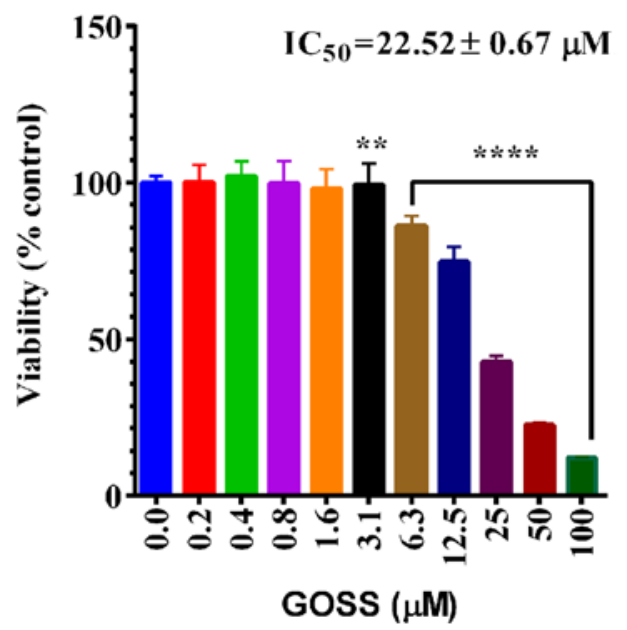

B MM-468 cells

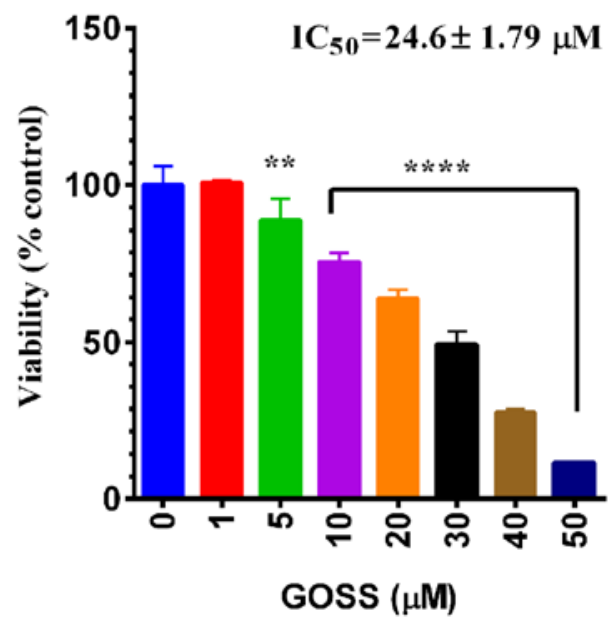

Figure 1. Effect of GOSS on the viability of MM-231 and MM-468 TNBC cell lines. Cells were treated for 24 h with GOSS at concentration ranges of 0-100 $\mu \mathrm{M}(\mathrm{A})$ and 0-50 $\mu \mathrm{M}(\mathrm{B})$ in MM-231 and MM-468 cells, respectively. The graph shows the viability data expressed as percentages of cell survival compared to the control. The data points represent the mean \pm SEM of three independent studies, $n=4$ each. The significance of the difference between the control and treated groups was determined using one-way analysis of variance (ANOVA) followed by Bonferroni's multiple comparisons test. The difference was considered significant at ${ }^{* *} \mathrm{P}<0.01$ and ${ }^{* * * *} \mathrm{P}<0.0001$. GOSS, gossypol; MM-231, MDA-MB-231; MM-468, MDA-MB-468; TNBC, triple-negative breast cancer; $\mathrm{IC}_{50}$, half maximal inhibitory concentration.

effect was quantified within 5-10 min on a FACSCalibur flow cytometer (BD Biosciences, San Jose, CA, USA). For each sample, $1 \times 10^{4}$ cells were examined and CellQuest software (BD Biosciences) was used for acquisition and data analysis.

Reverse transcription-polymerase chain reaction (RT-PCR) apoptosis array. This experiment was performed based on the data of the apoptosis assay using the concentrations that did not cause a considerable necrosis effect in either cell line: $25 \mu \mathrm{M}$ in MM-231 cells and $20 \mu \mathrm{M}$ in MM-468 cells. Briefly, two T-75 flasks of $10 \times 10^{6}$ cells (control and treated for each cell line) were incubated overnight at $37^{\circ} \mathrm{C}$ and for an additional 24-h in the absence or presence of the previously indicated concentrations of the test compound. The cells from each sample were pelleted and mixed with $1 \mathrm{ml}$ of TRIzol reagent to isolate total RNA. Subsequently, $0.2 \mathrm{ml}$ of chloroform was added to each sample, vortexed, incubated at room temperature (RT) for 2-3 $\mathrm{min}$ and centrifuged for $15 \mathrm{~min}$ at $10,000 \mathrm{x} \mathrm{g}$ and at $2-8^{\circ} \mathrm{C}$. The aqueous phase was collected and mixed with $0.5 \mathrm{ml}$ of isopropyl alcohol to precipitate the RNAs. The RNA pellets were then dissolved in $\sim 30-50 \mu \mathrm{l}$ of Nuclease-free water to measure RNA quantity and quality in each sample using a NanoDrop spectrophotometer (NanoDrop Technologies; Thermo Fisher Scientific, Inc.). Finally, cDNA representing the control or treated cells was synthesized using the iScript ${ }^{\mathrm{TM}}$ cDNA Synthesis kit according to the manufacturer's protocol. The obtained cDNA was reconstituted in Nuclease-free water, and the 96-well apoptosis array was loaded with $10 \mu \mathrm{l}$ each of the reconstituted cDNA (2.3 ng) and SsoAdvanced $^{\mathrm{TM}}$ Universal SYBR $^{\circledR}$ Green Supermix (Bio-Rad Laboratories) and then placed for $5 \mathrm{~min}$ in a shaker and centrifuged at 1,000 x $\mathrm{g}$ for $1 \mathrm{~min}$. The PCR run was established with 39 cycles of denaturation as follows: 30 -sec activation at $95^{\circ} \mathrm{C}, 10-\mathrm{sec}$ denaturation at $95^{\circ} \mathrm{C} ; 20$-sec annealing at $60^{\circ} \mathrm{C}$; and $31-\sec$ extension at $65^{\circ} \mathrm{C}$ using a Bio-Rad CFX96
Real-Time System (Bio-Rad Laboratories). All real-time PCRs were performed in triplicate for each cell line. Gene expression was analyzed using the CFX 3.1 Manager software (Bio-Rad Laboratories) and verified with Student's t-test.

Statistical analysis. Data for this study were analyzed using GraphPad Prism 6.2 software (GraphPad Software, Inc., San Diego, CA, USA). All data points were obtained from the average of at least two independent studies and are expressed as the mean $\pm \mathrm{SEM}$. For the viability assay, $\mathrm{IC}_{50}$ values were determined by non-linear regression with the $\mathrm{R}^{2}$ best fit and the lowest $95 \%$ confidence interval. In both the viability and apoptosis assays, the significance of the difference between each control and its related treatment group was determined using one-way analysis of variance (ANOVA) followed by Bonferroni's multiple comparison test. For both the proliferation and clonogenic assays, the statistical analysis was performed with two-way analysis of variance (ANOVA) between each exposure period and other(s) followed by Bonferroni's multiple comparison test. Overall, a difference was considered significant at ${ }^{*} \mathrm{P}<0.05$ and ${ }^{* * * *} \mathrm{P}<0.0001$ (as indicated in the figures and legends). Gene expression was analyzed using CFX 3.1 Manager software (Bio-Rad Laboratories) and verified with the Student's t-test.

\section{Results}

The anticancer effects of GOSS were examined in both MM-231 and MM-468 cell lines. As indicated in Fig. 1A and B, a highly significant effect $(\mathrm{P}<0.0001)$ of GOSS on cell viability was found in MM-231 and MM-468 cells at different concentrations of the compound (6.3-100 and 10-50 $\mu \mathrm{M}$ in MM-231 and MM-468, respectively). In both cell lines, the obtained $\mathrm{IC}_{50}$ did not show a significant difference in response to the compound $\left(\mathrm{IC}_{50}=22.52 \pm 0.67\right.$ and $24.6 \pm 1.79 \mu \mathrm{M}$ for MM-231 and MM-468 cells, respectively). 
A

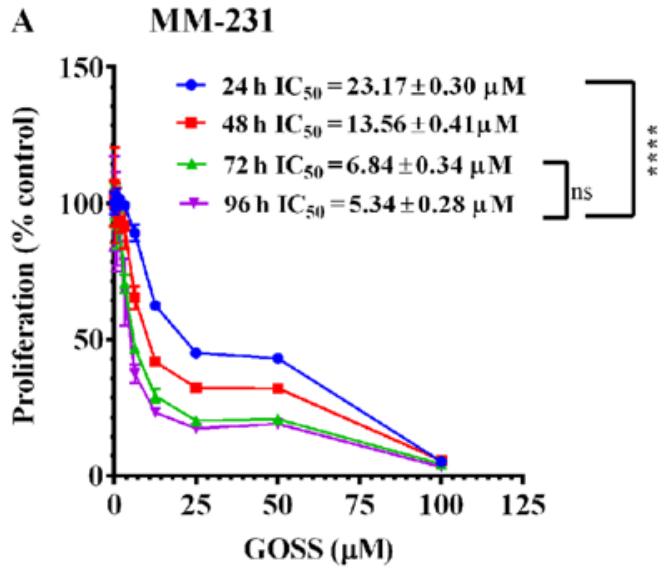

C
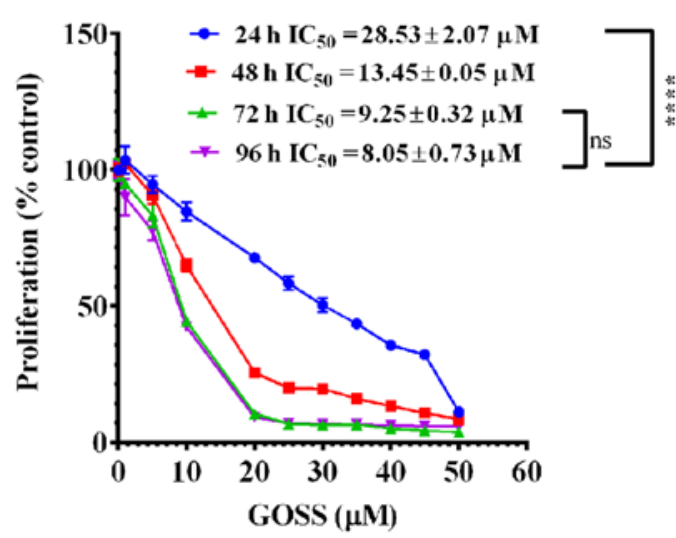

B MM-231

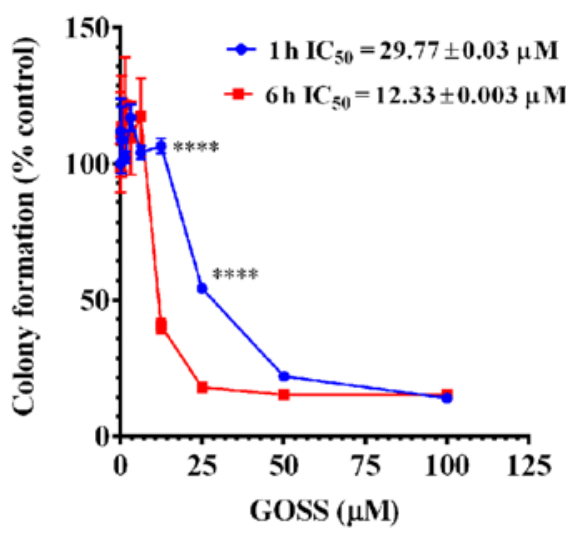

D MM-468

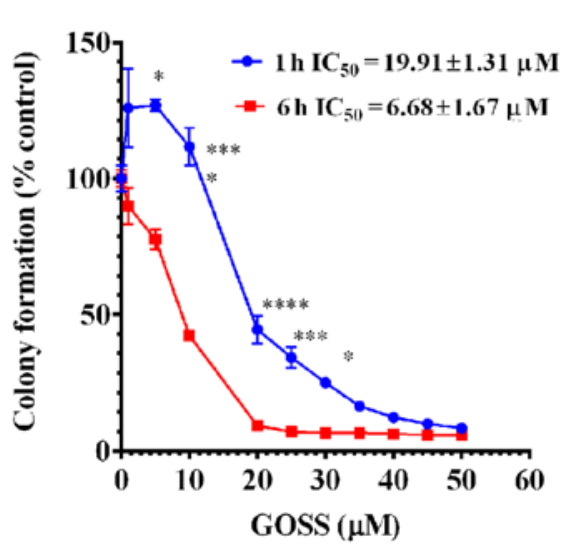

Figure 2. Effect of GOSS on proliferation and colony formation in MM-231 and MM-468 TNBC cell lines. In the cell proliferation study, cells were incubated for $96 \mathrm{~h}$ with GOSS at concentration ranges of 0-100 $\mu \mathrm{M}(\mathrm{A})$ and of 0-50 $\mu \mathrm{M}(\mathrm{C})$ in MM-231 and MM-468 cells, respectively. For the colony formation assay, MM-231 (B) and MM-468 (D) cells were exposed to similar concentrations of GOSS for either 1 or $6 \mathrm{~h}$ and then washed and allowed to grow in regular cell culture media for 7 days. In both assays, each data point represents the mean \pm SEM of three independent experiments, $n=4$ each. The significance of the difference between the different exposure periods was calculated using two-way analysis of variance (ANOVA) followed by Bonferroni's multiple comparisons test, and ${ }^{* * * * *} \mathrm{P}<0.0001$ indicates a statistically significant difference between $24-\mathrm{h}$ vs. other exposure periods, while a non-significant difference was found between the 72- vs. 96-h exposure periods. Similarly, ${ }^{* * * * *} \mathrm{P}<0.0001,{ }^{* * * *} \mathrm{P}<0.001$ and ${ }^{*} \mathrm{P}<0.05$ indicate a statistically significant difference in the colony formation inhibition between the 1- vs. 6-h exposure periods at different concentrations. GOSS, gossypol; TNBC, triple-negative breast cancer; MM-231, MDA-MB-231; MM-468, MDA-MB-468; $\mathrm{IC}_{50}$, half maximal inhibitory concentration; ns, not significant.

To measure the growth inhibitory potency of GOSS in MM-231 and MM-468 cell lines, both antiproliferative and clonogenicity assays were performed. In both cell lines, GOSS inhibited cell proliferation and colony formation in a dose- and time-dependent manner compared to the control cells (Fig. 2). The inhibition of cell proliferation, as indicated by the reduction of resazurin and verified by the decrease in the $\mathrm{IC}_{50}$ values at the different periods of exposure, is shown in Fig. 2A and C (MM-231 and MM-468 cells, respectively). Indeed, the $\mathrm{IC}_{50}$ values were reduced significantly $(\mathrm{P}<0.0001)$, from 23.17 to $5.34 \mu \mathrm{M}$ in MM-231 cells and from 28.53 to $8.05 \mu \mathrm{M}$ in MM-468 cells at the 24 -vs. 96 -h exposure periods. Furthermore, in both cell lines, GOSS significantly inhibited cell proliferation $(\mathrm{P}<0.0001)$ at the 24 -h treatment period vs. other periods, but there was no significant difference in cell proliferation inhibition between the 72-vs. 96-h treatment period.

The data also showed that GOSS significantly inhibited colony formation in both MM-231 and MM-468 cells (Fig. 2B and D). In MM-231 cells, a significant delay in colony formation $(\mathrm{P}<0.0001)$ was observed between the 1- vs. the 6-h exposure periods following treatment with 12.5 and $25.0 \mu \mathrm{M}$ GOSS (Fig. 2B). A significant difference was also observed in its counterpart cell line, MM-468 $(\mathrm{P}<0.05-\mathrm{P}<0.0001)$, throughout the concentration range of 5-30 $\mu \mathrm{M}$, as shown in Fig. 2D.

Nonetheless, the data indicate that GOSS has similar growth inhibitory potency on both racially distinct cell lines. The colony formation assessment indicated that after a 6-h treatment period, GOSS was $\sim 2$-fold more effective in MM-468 cells $\left(\mathrm{IC}_{50}=6.68 \pm 1.67 \mu \mathrm{M}\right)$ than in MM-231 cells $\left(\mathrm{IC}_{50}=12.33 \pm 0.003 \mu \mathrm{M}\right)$ (Fig. 2B and D).

On the other hand, the $\mathrm{IC}_{50}$ value of cells after $72 \mathrm{~h}$ of exposure to doxorubicin was $1.69 \pm 0.11$ and $0.23 \pm 0.003$ in MM-231 and MM-468 cells, respectively, with $\mathrm{P}<0.05-\mathrm{P}<0.0001$ (Fig. 3). The apoptotic effect of GOSS on both MM-231 and MM-468 TNBC cells was examined to confirm apoptosis mediation of the antiproliferative effect and colony formation inhibition of GOSS. After $24 \mathrm{~h}$ of exposure, a gradual but significant increase in the number of apoptotic cells $(\mathrm{P}<0.0001)$ was observed in a dose-dependent manner (Fig. 4A and B). Additionally, the results indicated that MM-468 cells were 


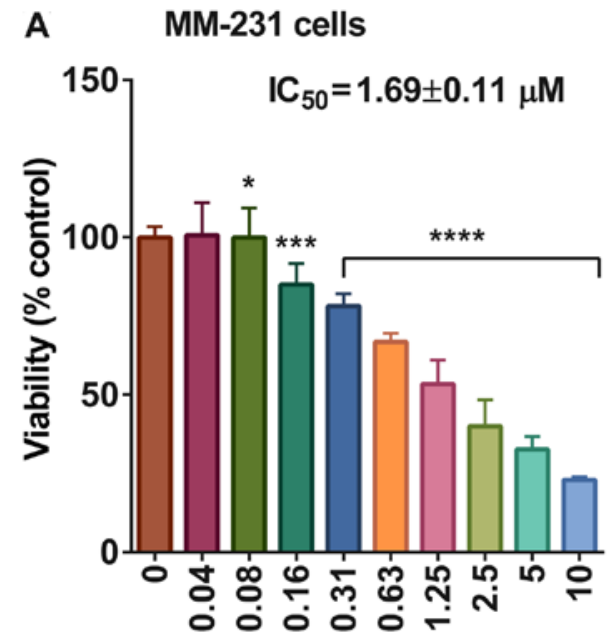

Doxorubicin $(\mu \mathrm{M})$

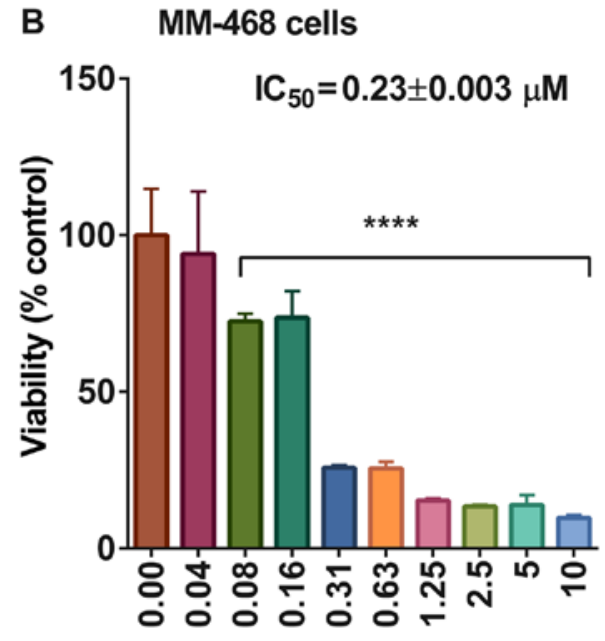

Doxorubicin $(\mu \mathrm{M})$

Figure 3. Effect of doxorubicin on proliferation in (A) MM-231 and (B) MM-468 TNBC cell lines. Both cell lines were incubated for $72 \mathrm{~h}$ with doxorubicin at concentration ranges of 0-10 $\mu \mathrm{M}$. Each point represents the mean \pm SEM of two independent experiments, $\mathrm{n}=4$ each. The graph shows the proliferation rate expressed as percentages compared to the control. The significance of the difference between the control and treated groups was determined using one-way analysis of variance (ANOVA) followed by Bonferroni's multiple comparisons test. The difference was considered significant at ${ }^{*} \mathrm{P}<0.05$, ${ }^{* * *} \mathrm{P}<0.001$ and ${ }^{* * * * *} \mathrm{P}<0.0001$. TNBC, triple-negative breast cancer; MM-231, MDA-MB-231; MM-468, MDA-MB-468; $\mathrm{IC}_{50}$, half maximal inhibitory concentration.

\section{A MM-231 cells}

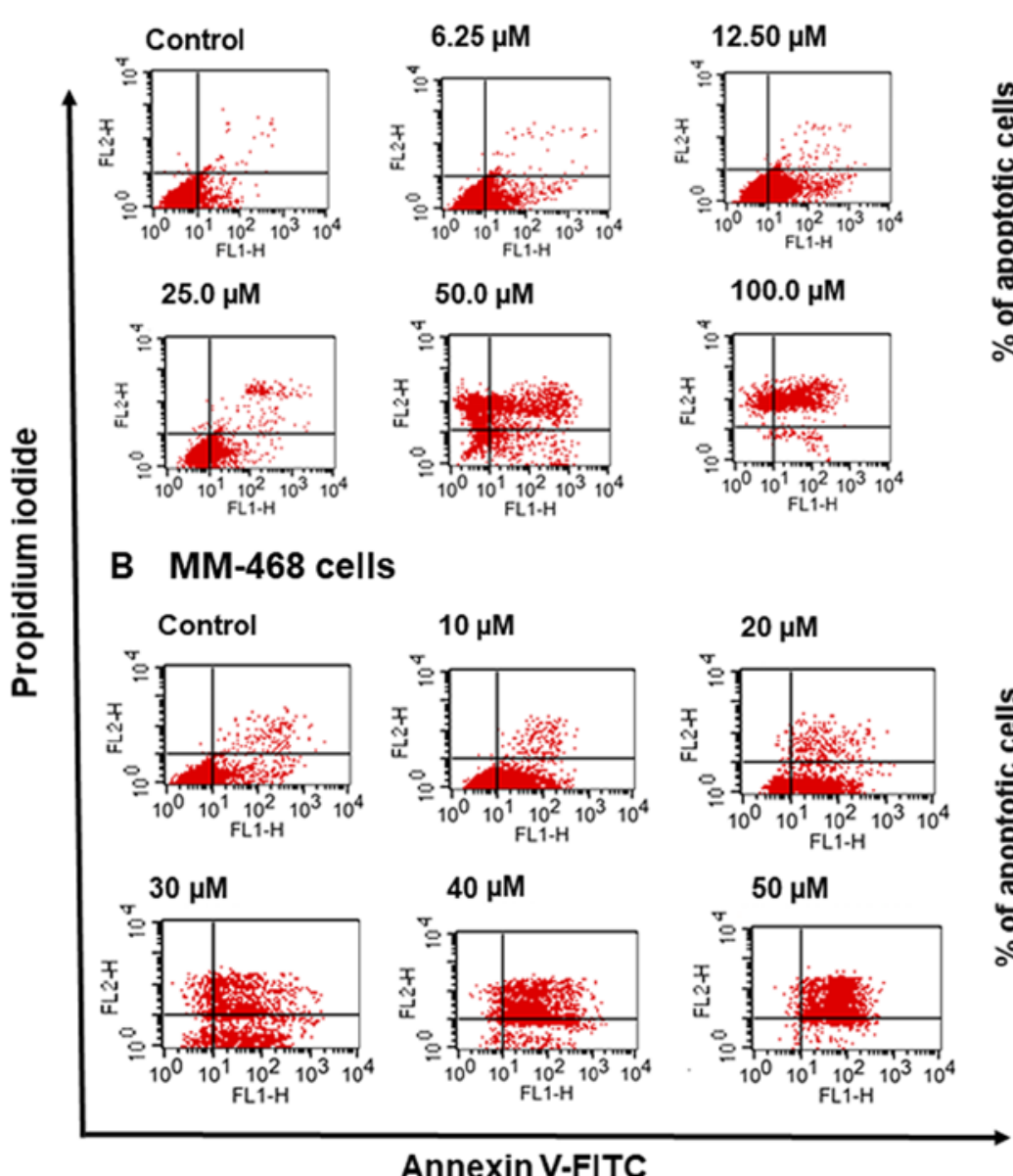

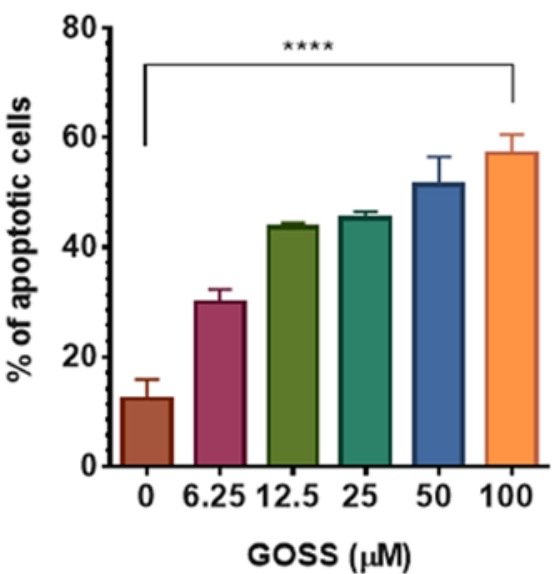

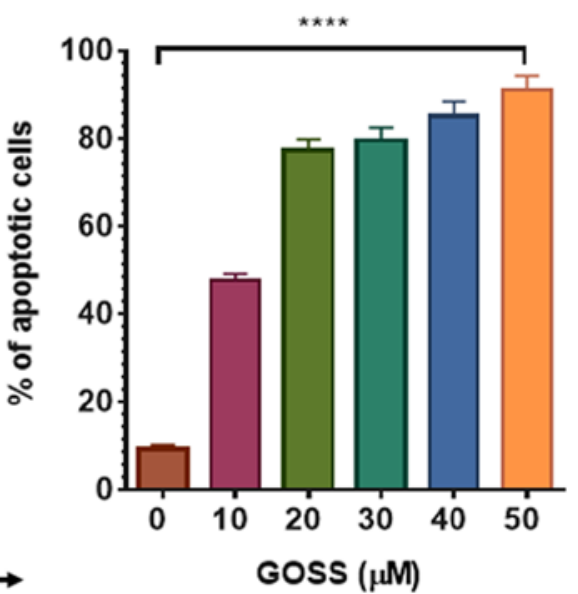

Figure 4. Apoptotic effect of GOSS on (A) MM-231 and (B) MM-468 TNBC cell lines. Cells were exposed to GOSS for $24 \mathrm{~h}$ at concentrations ranging from 0 to $100 \mu \mathrm{M}$ for MM-231 cells and 0-50 $\mu \mathrm{M}$ for MM-468 cells. Control cells were treated with DMSO at the highest exposure dose $(<0.1 \%)$. An Annexin V-FITC apoptosis kit was used to label treated/control cells, and a FACSCalibur flow cytometer was used to analyze the percentage of apoptotic cells compared to the DMSO-treated control cells. Each data point represents the mean \pm SEM of two independent studies, $n=3$ each. The significance of the difference between control vs. each treatment was calculated using one-way analysis of variance (ANOVA) followed by Bonferroni's multiple comparisons test. ${ }^{* * * * *} \mathrm{P}<0.0001$ confirmed the statistically significant difference. GOSS, gossypol; TNBC, triple-negative breast cancer; MM-231, MDA-MB-231; MM-468, MDA-MB-468; DMSO, dimethyl sulfoxide. 
A

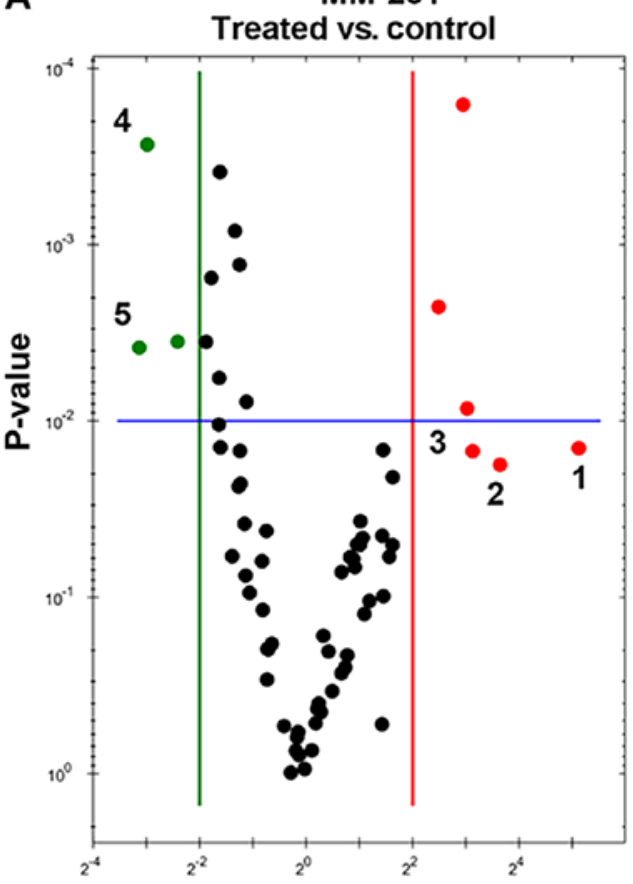

Relative normalized expression of treated cells
B

Treated vs. control

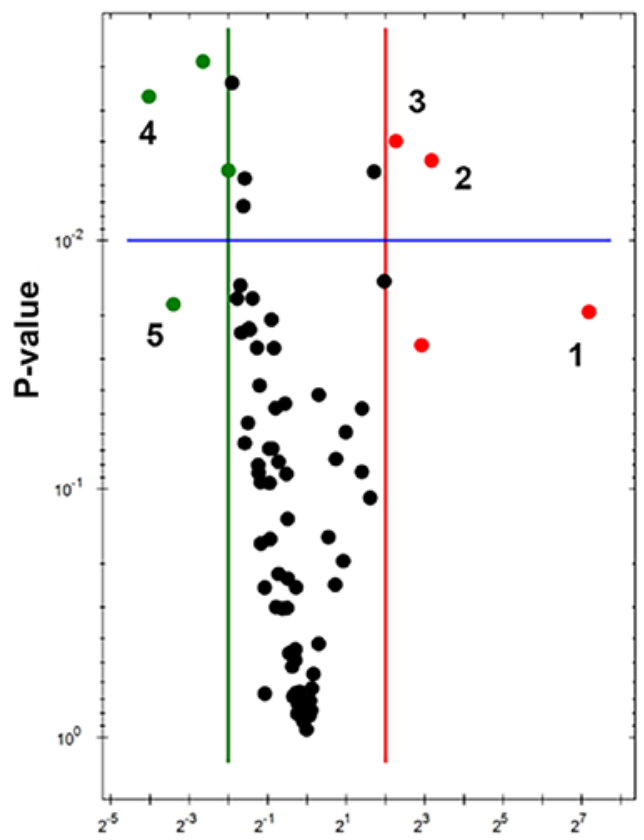

Relative normalized expression of treated cells

Figure 5. Scatter plots for MM-231 and MM-468 TNBC cells. Cells were exposed to GOSS for $24 \mathrm{~h}$ at a concentration of $25 \mu \mathrm{M}$ in MM-231 cells and $20 \mu \mathrm{M}$ in MM-468 cells and normalized the mRNA expression of target genes for the control vs. treated MM-231 (A) and MM-468 (B) cells. Based on the threshold set (green and red lines), the plot images show the following changes in apoptosis-related gene expression: Upregulation, red dots; downregulation, green dots; no change, black dots. In both cell lines and based on the fold changes, the most upregulated genes are enumerated from 1-3, while 4-5 refer to the downregulated genes. In MM-231 cells, GADD45A, TNFRSF9 and BNIP3 were upregulated, while BIRC5 and DAPK1 were downregulated. Similarly, in MM-468 cells, $T N F$, GADD45A and BNIP3 were upregulated, while BIRC5 and TP73 were downregulated. GOSS, gossypol; TNBC, triple-negative breast cancer; MM-231, MDA-MB-231; MM-468, MDA-MB-468; GADD45A, growth arrest and DNA-damage-inducible 45 alpha protein; TNFRSF9, tumor necrosis factor receptor superfamily 9; BNIP3, BCL2 interacting protein 3; BIRC5, baculoviral IAP repeat containing 5; DAPK1, death-associated protein kinase; TP73, tumor protein 73 .

Table I. mRNA gene expression changes in MM-231 and MM-468 TNBC cells.

Control vs. treated MM-231 cells

\begin{tabular}{|c|c|c|c|c|c|}
\hline Target gene & Fold changes & P-value & Target gene & Fold changes & P-value \\
\hline$G A D D 45 A$ & +33.42 & 0.028 & $T N F$ & +158.98 & 0.023 \\
\hline TNFRSF9 & +12.35 & 0.018 & $G A D D 45 A$ & +9.22 & 0.005 \\
\hline BNIP3 & +8.75 & 0.015 & $B N I P 3$ & +4.84 & 0.004 \\
\hline BIRC5 & -7.96 & 0.0003 & BIRC5 & -24.32 & 0.002 \\
\hline$D A P K 1$ & -14.79 & 0.0012 & TP73 & -8.65 & 0.037 \\
\hline
\end{tabular}

The left portion of the table presents the fold changes in gene expression (+/-) in MM-231 cells following treatment with $25 \mu \mathrm{M}$ GOSS In contrast, the right portion presents the fold changes in gene expression (+/-) in MM-468 cells following treatment with $20 \mu \mathrm{M}$ GOSS. MM-231, MDA-MB231, MM-468, MDA-MB-468; TNBC, triple-negative breast cancer; GOSS, gossypol; GADD45A, growth arrest and DNA-damage-inducible 45 alpha protein; TNFRSF9, tumor necrosis factor receptor superfamily member 9; BNIP3, BCL2 interacting protein 3; BIRC5, baculoviral IAP repeat containing 5; DAPK1, death-associated protein kinase; TNF, tumor necrosis factor; TP73, tumor protein 73 . $\mathrm{P}<0.05$ was considered as statistically significant.

more sensitive (almost 2-fold more sensitive) to GOSS than MM-231 cells, and $90 \%$ of the MM-468 cells analyzed were in the apoptotic phase following treatment with $50 \mu \mathrm{M}$ GOSS, as shown in Fig. 4B, whereas $<60 \%$ of MM-231 cells analyzed exhibited apoptotic effects at $100 \mu \mathrm{M}$ (Fig. 4A). The obtained data show the strong apoptotic effect of GOSS on both TNBC cell lines.

Quantitative real-time PCR (qRT-PCR) was performed in both GOSS-treated cell lines to identify the genes related to GOSS-induced apoptosis. The profiling of normalized 


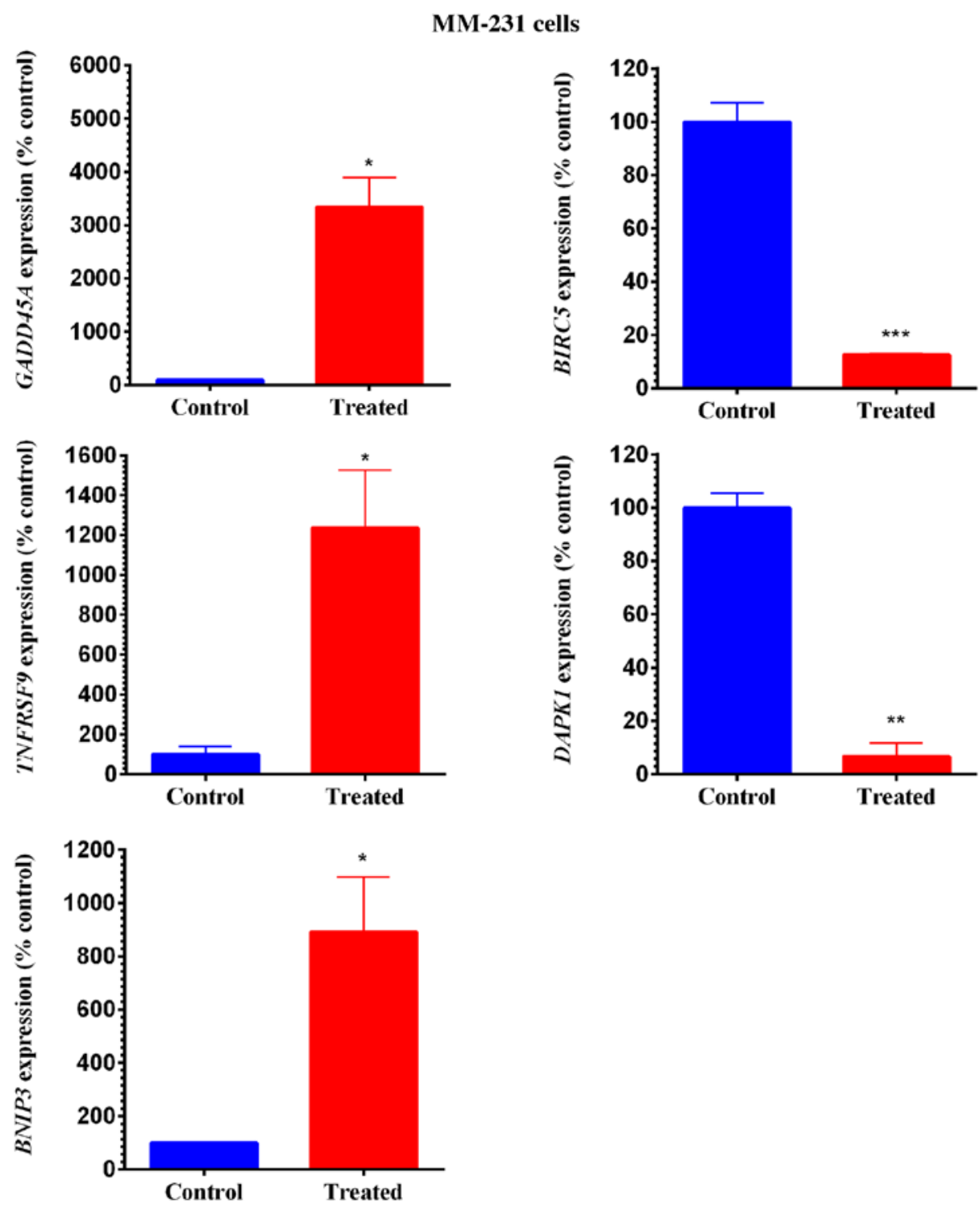

Figure 6. Gene expression quantification in MM-231 cells. Cells were exposed to GOSS for $24 \mathrm{~h}$ at a concentration of $25 \mu \mathrm{M}$. Normalized mRNA data indicate a significant increase in three genes (GADD45A, TNFRSF9 and BNIP3) in the GOSS-treated MM-231 cells vs. control cells, while two genes were significantly inhibited (BIRC5 and DAPK1). The data points represent the mean \pm SEM of three independent studies. The significance of the difference was determined using an unpaired t-test between the resting vs. treated cells. The difference was considered significant at ${ }^{*} \mathrm{P}<0.05,{ }^{* * *} \mathrm{P}<0.01$ and ${ }^{* * * *} \mathrm{P}<0.001$. GOSS, gossypol; MM-231, MDA-MB-231; GADD45A, growth arrest and DNA-damage-inducible 45 alpha protein; TNFRSF9, tumor necrosis factor receptor superfamily 9; $B N I P 3$, BCL2 interacting protein 3; BIRC5, baculoviral IAP repeat containing 5; DAPK1, death-associated protein kinase.

mRNA expression in both cell lines provided insights into the influence of the compound on many apoptosis-related genes. In this study, we identified apoptosis-related genes that were significantly upregulated/downregulated by the compound. Overall, in both cell lines, as shown in Fig. 5A and B, the visually recognized red dots represent the upregulated genes, while the green dots represent those that were downregulated by GOSS.

The specifically impacted genes were quantified and are presented in Figs. 6 and 7. In MM-231 cells, GOSS significantly $(\mathrm{P}<0.05)$ increased the expression of three genes (GADD45A, TNFRSF9 and BNIP3) (Fig. 6). Similarly, in MM-468 cells, GADD45A and BNIP3 were upregulated by GOSS treatment $(\mathrm{P}<0.05-\mathrm{P}<0.01)$ (Fig. 7). Nevertheless, the $G A D D 45 A$ gene was significantly upregulated in both cell lines; the fold-increase in MM-231 cells was 33.42 and that in MM-468 cells was 9.22 (Table I). Moreover, the measured upregulation of BNIP3 in MM-231 cells was approximately twice that of its counterpart cell line, MM-468 (Figs. 6 and 7 and Table I). Two members of the $T N F /$ receptor family of genes were also increased. TNF was profoundly overexpressed by 159-fold in MM-468 cells, and an $\sim 12$-fold increase in the TNF receptor TNFRSF9 was found in MM-231 cells. In contrast, GOSS significantly repressed the mRNA expression of many apoptosis-related genes $(\mathrm{P}<0.05-\mathrm{P}<0.001)$. More than $90 \%$ inhibition $(\geq 8$-fold decrease) in BIRC5 was observed in both cell lines, in addition to a 14.79- decrease and an 8.65-fold decrease in DAPK1 and TP73 in MM-231 and MM-468 cells, respectively (Table I). Notably, the compound GOSS did not show a significant effect on the expression of the different caspases (data not shown). 


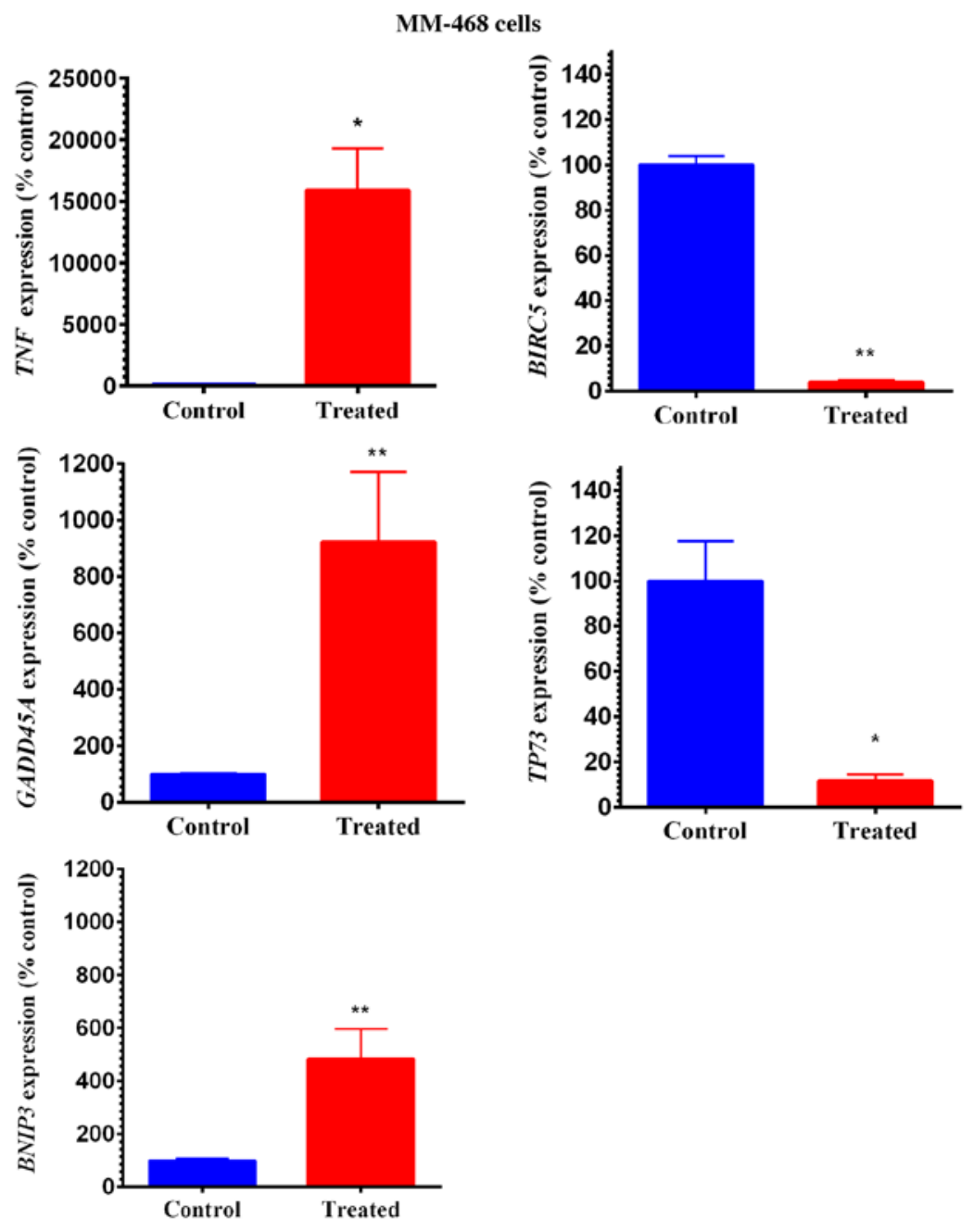

Figure 7. Gene expression quantification in MM- 468 cells. Cells were exposed to GOSS for $24 \mathrm{~h}$ at a concentration of $20 \mu \mathrm{M}$. Normalized mRNA data indicate a significant increase in three genes (TNF, GADD45A and BNIP3) in the GOSS-treated MM-468 cells vs. control cells, while two genes were significantly inhibited (BIRC5 and TP73). The data points represent the mean \pm SEM of three independent studies. The significance of the difference was determined using an unpaired t-test between the resting vs. treated cells. The difference was considered significant at ${ }^{*} \mathrm{P}<0.05$ and ${ }^{* *} \mathrm{P}<0.01$. GOSS, gossypol; MM- 468 , MDA-MB-468; $T N F$, tumor necrosis factor; GADD45A, growth arrest and DNA-damage-inducible 45 alpha protein; BNIP3, BCL2 interacting protein 3; BIRC5, baculoviral IAP repeat containing 5; TP73, tumor protein 73 .

\section{Discussion}

Apoptosis is a pivotal cellular process that maintains genomic integrity (52). Genomic alterations, including the upregulation of genes involved in DNA synthesis, cell division, proliferation, and cell cycle progression, have been shown to be key mediators in BC development and progression. $(53,54)$. In particular, the apoptosis methylation-mediated silencing of genes is the most important epigenetic mechanism for regulating normal gene expression (1).

The present study provides evidence for the anticancer effect of the natural polyphenol gossypol (GOSS) in two triple-negative breast cancer (TNBC) cell lines: MDA-MB-231 (MM-231) and MDA-MB-468 (MM-468). However, future studies are needed to determine the relative toxicity of GOSS in TNBC cells compared to non-cancer cells. This compound impacted the molecular apoptotic pathway by altering the mRNA gene expression of specific apoptosis-related genes (Figs. 5-7 and Table I). Overall, the obtained data are consistent with those from previous studies $(22,29,35)$. This study shows similar cytotoxic (Fig. 1A and B) and antiproliferative (Fig. 2A and C) effects in both cell lines. Notably, MM-468 cells showed a higher response during the colony formation (Fig. 2B and D), doxorubicin antiproliferation (Fig. 3) and apoptotic (Fig. 4) assays. However, doxorubicin was an extremely potent antiproliferative agent, and the obtained $\mathrm{IC}_{50}$ values were compatible with those previously reported (51). However, meager previous investigations have examined GOSS effects on diet, and a previous study on women with refractory metastatic breast cancer (BC) indicated that the maximally tolerated dose of GOSS was $40 \mathrm{mg} /$ day (55).

In normal cells, several molecular pathways control apoptosis and orchestrate the balance between cell proliferation and cell death to maintain homeostasis. However, in cancer cells, triggering the genes involved in these signaling pathways leads to uncontrolled cell proliferation and tumorigenesis. Therefore, understanding the mechanisms of apoptosis and targeting the expression of these apoptotic genes are crucial in the development of targeted cancer therapy (56). The profiling of apoptosis-related genes in both MM-231 and MM-468 TNBC cell lines revealed that GOSS could induce both intrinsic and extrinsic apoptotic pathways. In the present study, GOSS was found to upregulate the proapoptotic genes 
GADD45A, BNIP3, TNF and TNFRSF9, the critical initiators of the extrinsic apoptotic pathway. Moreover, the compound was efficiently able to attenuate the expression of the survivin BIRC5 gene, a well-known inhibitor of intrinsic apoptosis, as well as two additional proapoptotic genes, DAPK1 and TP73. Although GOSS increased GADD45A expression in both cell lines, the gene was highly upregulated in MM-231 cells (33-fold increase) compared with MM-468 cells (Table I). The proapoptotic gene, growth arrest and DNA damage-induced 45 alpha $(G A D D 45 A)$ is a member of the stress sensor family GADD45, which normally controls many cellular functions, including DNA repair, apoptosis, cell cycle regulation and genotoxic stress (57). However, GADD45 genes are epigenetically inactivated in different types of cancer cells (1). In TNBC, there is a strong association between a low level of the GADD45A gene and the lack of the three hormone receptors, ER, PR and Her2/neu (58). Moreover, in BC, the hypermethylated $G A D D 45 A$ gene is regulated by two major tumor suppressor proteins: p53 and BRCA1 (59). Furthermore, the upregulation of $G A D D 45 A$ may be involved in apoptosis by activating the JNK and/or p38 MAPK signaling pathways $(60,61)$.

In both MM-231 and MM-468 cell lines, GOSS upregulated BNIP3 expression. However, the increase in gene expression in MM-231 cells was 2 -fold greater than that in its counterpart cell line, MM-468 (Figs. 6 and 7 and Table I). The death-inducing mitochondrial protein $B N I P 3$ is a member of the proapoptotic Bcl-2 family of proteins that promotes both apoptosis and autophagy. BNIP3 contains a C-terminal transmembrane (TM) domain as well as a sequence resembling a BH3 domain, and both are essential for apoptosis induction $(62,63)$. Moreover, BNIP3 mediates novel necrosis-like mechanisms by opening the mitochondrial permeability transition (PT) pore independent of caspase activation, cytochrome $c$ release, Apaf-1, or the nuclear translocation of apoptosis-inducing factor (64). Similar to our finding, in $\mathrm{BC}$, the induction of BNIP3 was found to induce apoptosis via (FAS) inhibition, which leads to the suppression of cell proliferation $(63,65)$.

Various stimuli can trigger apoptosis, one of which is the signaling protein $T N F$ superfamily (66). In the present study, $T N F$, also known as the $T N F$ - $\alpha$ gene (67), was the most upregulated in MM-468 cells. The compound GOSS markedly increased the expression of TNF by 159-fold (Fig. 7 and Table I). The fact that $T N F$ is the most potent inducer of apoptosis in the TNF superfamily (68) can explain the higher response of MM-468 cells to the apoptotic effect induced by the compound. Furthermore, multifunctional TNF can trigger both cell proliferation and cell death. In particular, the upregulation of NF- $\mathrm{NB}$-related genes increases cell viability and proliferation. However, the activation of different caspases leads to apoptosis induction $(68,69)$. Contrary to healthy cells, the multifunctional proinflammatory gene $T N F-\alpha$ is detected in many cancers, including ovarian, renal and breast (70-72), and has been found to increase cell survival and proliferation through NF- $\kappa \mathrm{B}$ activation (73). Additionally, the TNF superfamily also plays a crucial role in regulating tissue homeostasis by activating the extrinsic apoptotic pathway (74) and triggering various signaling pathways, including the activation of caspases, impacting proliferation and inducing apoptosis (75).

In MM-231 cells, a 12-fold upregulation in $T N F$ receptor superfamily 9 (TNFRSF9 also known as CD137,4-1BB, or ILA) was found (Fig. 5 and Table I). TNFRSF9 is a costimulatory receptor that is involved in apoptosis. TNFRSF9 is expressed by activated monocytes and lymphocytes (76), while its ligand is expressed by monocytes and B cells (3). In MM-231 cells, the most important ability is for CD137 to synergize the apoptotic effect of suberoylanilide hydroxamic acid (SAHA), a histone deacetylase (HDAC) inhibitor with anticancer properties (77).

GOSS markedly and similarly decreased the expression of BIRC5 in both TNBC cell lines, as shown in Figs. 5 and 6 and Table I. BIRC5, or the survivin gene is the smallest member of the IAP family (78). In the human genome, the gene encoding BIRC5 is among one of the highly specific tumor genes (79) that prevent apoptosis by inhibiting the activity of different caspases (80), leading to aggressive tumor behavior and poor clinical outcomes (81). Compared to normal tissues, an increase in BIRC5 expression has been demonstrated in different types of cancers, including pancreatic (82), lung (83), colon and ovarian (84), esophageal and skin (85), colorectal and lymphoma (86) and prostate (87). In particular, in TNBC cells, the highly expressed BIRC5 is considered a marker in the early diagnosis of $\mathrm{BC}$ and was found to correlate with the resistance to radiation and chemotherapy $(79,81,84)$. Additionally, two more apoptosis-related genes, $D A P K 1$ and $T P 73$, were significantly downregulated in GOSS-treated MM-231 and MM-468 cells, respectively (Figs. 6 and 7 and Table I).

The proapoptotic death-associated protein kinase 1 $(D A P K 1)$ is characterized by its C-terminal death domain and plays an essential role in cell survival, proliferation and death (88). Compared to normal cells, lower expression of DAPK1 mRNA has been observed in different cancer cell lines; however, in the presence of $T N F$ - $\alpha$, the gene can decrease cell growth (89). The present study indicated repression of $D A P K 1$ gene expression in treated MM-231 cells. In addition, TNF- $\alpha$-stimulated apoptosis was inhibited by overexpression of DAPK1 (89). Taken together, our results suggest that $D A P K 1$ downregulation may be a promising target in cancer therapy, particularly in MM-231 TNBC cells.

Surprisingly, the compound GOSS downregulated the gene TP73 in MM-468 cells. Tumor protein p73 (TP73) is a member of the TP53 (p53) tumor-suppressor gene family. This family is characterized by a proapoptotic role (90) and is involved in cell cycle regulation and apoptosis (91). In TNBC MM-231 cells $(92,93)$, upregulated TP73 can replace (92) or activate P53 gene transcription, induce apoptosis and considerably affect tumor progression (94). On a molecular basis, gene polymorphisms can modify their specific functions (95). Certainly, there is an association between the TP73 polymorphism (G4C14-A4T14) and cancer risk (94). Although it was not found in BC, in sympathetic neurons, the $p 73$ isoform lacking the transactivation domain has been found to act as a neuronal antiapoptotic protein and counteract the proapoptotic function of p53 (90).

The data obtained in this study provide evidence that the apoptotic effect of GOSS is related to either the upregulated proapoptotic genes and TNF- $\alpha$ or repression of the inhibitor of apoptosis genes or both. However, previous studies have shown the ability of GOSS to induce apoptotic effects by DNA fragmentation (96), DNA synthesis inhibition (30), and arresting S-phase without affecting RNA and protein synthesis (97). The molecular mechanism of GOSS-induced apoptosis was previously determined to be associated with the interaction between 
the compound and the antiapoptotic proteins Bcl-2 and Bcl-xl in the mitochondria (98). In other words, the $\mathrm{BH} 3$ mimetic GOSS ectopically expresses Bcl-2 and Bcl-xL (25), inhibiting the $\mathrm{Bcl}-2 / \mathrm{Mcl}-1$ pathway (33) and the heterodimerization of $\mathrm{Bcl}-\mathrm{xL} / \mathrm{Bcl}-2$ by releasing proapoptotic proteins (apoptosis-inducing factor, AIF) (37). GOSS can also induce apoptosis by releasing cytochrome $c$ and activating the proapoptotic protein Bak or Bax/Bak via conformational changes in overexpressed Bcl-2 (99,100). Moreover, inhibiting the phosphorylation of ERK1/2 and AKT, stimulating p38 and JNK1/2 protein phosphorylation, and inhibiting ErbB2 protein expression have been found to be mechanisms of GOSS-induced apoptosis (35).

In conclusion, the present study elucidated the genes involved in the apoptotic molecular mechanism of the polyphenol compound GOSS in two different TNBC cell models, MM-231 and MM-468. This study demonstrated that GOSS was more potent in MM-468 cells in inducing apoptosis and delaying colony formation. However, the impact of the compound on cell viability and proliferation was almost the same, and the data obtained did not show a considerable difference in cell response. In parallel, GOSS upregulated two proapoptotic genes (GADD45A and $B N I P 3)$ and attenuated the expression of BIRC5 in both MM-231 and MM-468 cells. Additionally, GOSS increased the expression of TNFRSF 9 and repressed DAPK1 in MM-231 cells, while an increase in $T N F$ gene expression (159-fold) and repression in TP73 were detected in MM-468 cells. The results obtained emphasize the importance of the polyphenol gossypol as a compound that can induce cancer cell apoptosis through extrinsic apoptosis-related genes. This compound may be targeted for TNBC treatment, particularly in African-American patients.

\section{Acknowledgements}

Not applicable.

\section{Funding}

The present study was supported by the National Institute of Minority Health and Health Disparity through grants G12 MD007582 and P20 MD006738.

\section{Availability of data and materials}

The datasets used during the present study are available from the corresponding author upon reasonable request.

\section{Authors' contributions}

Conceptualization of the study was achieved by SSM and KFAS. The research methodology was designed by SSM, HA, CC, NOZ, PM and KFAS. Formal analysis of the data was conducted by SSM and KFAS. Funding acquisition was accomplished by KFAS. Project administration was carried out by KFAS, and study resources were obtained by SSM and KFAS. Software analysis of data and figures was conducted by SSM and KFAS, and supervision of the research was conducted by KFAS. Writing of the original draft was undertaken by SSM, and writing, review and editing of the manuscript were carried out by SSM, NOZ, PM, HA, CC and KFAS. All authors read and approved the manuscript and agree to be accountable for all aspects of the research in ensuring that the accuracy or integrity of any part of the work are appropriately investigated and resolved.

\section{Ethics approval and consent to participate}

Not applicable.

\section{Patient consent for publication}

Not applicable.

\section{Competing interests}

The authors state that they have no competing interests.

\section{References}

1. Al-Romaih K, Sadikovic B, Yoshimoto M, Wang Y, Zielenska M and Squire JA: Decitabine-induced demethylation of 5 ' $\mathrm{CpG}$ island in GADD45A leads to apoptosis in osteosarcoma cells. Neoplasia 10: 471-480, 2008

2. Albain KS, Unger JM, Crowley JJ, Coltman CA Jr and Hershman DL: Racial disparities in cancer survival among randomized clinical trials patients of the Southwest oncology group. J Natl Cancer Inst 101: 984-992, 2009.

3. Alderson MR, Smith CA, Tough TW, Davis-Smith T, Armitage RJ, Falk B, Roux E, Baker E, Sutherland GR and Din WS: Molecular and biological characterization of human 4-1BB and its ligand. Eur J Immunol 24: 2219-2227, 1994.

4. Schulze-Osthoff K, Ferrari D, Los M, Wesselborg S and Peter ME: Apoptosis signaling by death receptors. Eur J Biochem 254: 439-459, 1998.

5. Mishra AP, Salehi B, Sharifi-Rad M, Pezzani R, Kobarfard F, Sharifi-Rad J and Nigam M: Programmed cell death, from a cancer perspective: An overview. Mol Diagn Ther 22: 281-295, 2018.

6. Wali JA, Masters SL and Thomas HE: Linking metabolic abnormalities to apoptotic pathways in Beta cells in type 2 diabetes. Cells 2: 266-283, 2013.

7. Miyashita T, Krajewski S, Krajewska M, Wang HG, Lin HK, Liebermann DA, Hoffman B and Reed JC: Tumor suppressor p53 is a regulator of bcl-2 and bax gene expression in vitro and in vivo. Oncogene 9: 1799-1805, 1994.

8. Kang MH and Reynolds CP: Bcl-2 inhibitors: Targeting mitochondrial apoptotic pathways in cancer therapy. Clin Cancer Res 15: 1126-1132, 2009.

9. Fulda S: Targeting inhibitor of apoptosis proteins (IAPs) for cancer therapy. Anticancer Agents Med Chem 8: 533-539, 2008.

10. Mannhold R, Fulda S and Carosati E: IAP antagonists: Promising candidates for cancer therapy. Drug Discov Today 15: 210-219, 2010.

11. DeSantis CE, Fedewa SA, Goding Sauer A, Kramer JL, Smith RA and Jemal A: Breast cancer statistics, 2015: Convergence of incidence rates between black and white women. CA Cancer J Clin 66: 31-42, 2016.

12. Anders CK and Carey LA: Biology, metastatic patterns, and treatment of patients with triple-negative breast cancer. Clin Breast Cancer 9 (Suppl 2): S73-S81, 2009.

13. Beaumont $\mathrm{T}$ and Leadbeater M: Treatment and care of patients with metastatic breast cancer. Nurs Stand 25: 49-56, 2011.

14. Fernández Y, Cueva J, Palomo AG, Ramos M, de Juan A, Calvo L, García-Mata J, García-Teijido P, Peláez I and García-Estévez L: Novel therapeutic approaches to the treatment of metastatic breast cancer. Cancer Treat Rev 36: 33-42, 2010.

15. Liu P, Kumar IS, Brown S, Kannappan V, Tawari PE, Tang JZ, Jiang W, Armesilla AL, Darling JL and Wang W: Disulfiram targets cancer stem-like cells and reverses resistance and cross-resistance in acquired paclitaxel-resistant triple-negative breast cancer cells. Br J Cancer 109: 1876-1885, 2013.

16. Craig DW, O'Shaughnessy JA, Kiefer JA, Aldrich J, Sinari S, Moses TM, Wong S, Dinh J, Christoforides A, Blum JL, et al: Genome and transcriptome sequencing in prospective metastatic triple-negative breast cancer uncovers therapeutic vulnerabilities. Mol Cancer Ther 12: 104-116, 2013. 
17. Cao H, Sethumadhavan $\mathrm{K}$ and Bland JM: Isolation of cottonseed extracts that affect human cancer cell growth. Sci Rep 8: 10458, 2018.

18. He Z, Zhang H and Olk DC: Chemical composition of defatted cottonseed and soy meal products. PLoS One 10: e0129933, 2015

19. Sharifi-Rad M, Fokou PVT, Sharopov F, Martorell M, Ademiluyi AO, Rajkovic J, Salehi B, Martins N, Iriti M and Sharifi-Rad J: Antiulcer agents: From plant extracts to phytochemicals in healing promotion. Molecules 23, pii: E1751: 2018.

20. Lin TS, Schinazi RF, Zhu J, Birks E, Carbone R, Si Y, Wu K, Huang L and Prusoff WH: Anti-HIV-1 activity and cellular pharmacology of various analogs of gossypol. Biochem Pharmacol 46: 251-255, 1993.

21. Janero DR and Burghardt B: Protection of rat myocardial phospholipid against peroxidative injury through superoxide-(xanthine oxidase)-dependent, iron-promoted fenton chemistry by the male contraceptive gossypol. Biochem Pharmacol 37: 3335-3342, 1988

22. Liu S, Kulp SK, Sugimoto Y, Jiang J, Chang HL, Dowd MK, Wan P and Lin YC: The (-)-enantiomer of gossypol possesses higher anticancer potency than racemic gossypol in human breast cancer. Anticancer Res 22: 33-38, 2002.

23. Moon DO, Kim MO, Lee JD and Kim GY: Gossypol suppresses NF-kappaB activity and NF-kappaB-related gene expression in human leukemia U937 cells. Cancer Lett 264: 192-200, 2008.

24. Voss V, Senft C, Lang V, Ronellenfitsch MW, Steinbach JP Seifert V and Kögel D: The pan-Bcl-2 inhibitor (-)-gossypol triggers autophagic cell death in malignant glioma. Mol Cancer Res 8: 1002-1016, 2010.

25. Zhang M, Liu H, Guo R, Ling Y, Wu X, Li B, Roller PP, Wang S and Yang D: Molecular mechanism of gossypol-induced cell growth inhibition and cell death of HT-29 human colon carcinoma cells. Biochem Pharmacol 66: 93-103, 2003.

26. Pang X, Wu Y, Wu Y, Lu B, Chen J, Wang J, Yi Z, Qu W and Liu M: (-)-Gossypol suppresses the growth of human prostate cancer xenografts via modulating VEGF signaling-mediated angiogenesis. Mol Cancer Ther 10: 795-805, 2011

27. Flack MR, Pyle RG, Mullen NM, Lorenzo B, Wu YW, Knazek RA, Nisula BC and Reidenberg MM: Oral gossypol in the treatment of metastatic adrenal cancer. J Clin Endocrinol Metab 76: 1019-1024, 1993

28. Moon DO, Choi YH, Moon SK, Kim WJ and Kim GY: Gossypol decreases tumor necrosis factor- $\alpha$-induced intercellular adhesion molecule-1 expression via suppression of NF- $\kappa \mathrm{B}$ activity. Food Chem Toxicol 49: 999-1005, 2011

29. Gilbert NE,O'Reilly JE,Chang CJ,Lin YC and BrueggemeierRW: Antiproliferative activity of gossypol and gossypolone on human breast cancer cells. Life Sci 57: 61-67, 1995.

30. Hu YF, Chang CJ, Brueggemeier RW and Lin YC: Gossypol inhibits basal and estrogen-stimulated DNA synthesis in human breast carcinoma cells. Life Sci 53: P1433-P1438, 1993.

31. Ye W, Chang HL, Wang LS, Huang YW, Shu S, Sugimoto Y, Dowd MK, Wan PJ and Lin YC: Induction of apoptosis by (-)-gossypol-enriched cottonseed oil in human breast cancer cells. Int J Mol Med 26: 113-119, 2010.

32. Lin J, Wu Y, Yang D and Zhao Y: Induction of apoptosis and antitumor effects of a small molecule inhibitor of Bcl-2 and Bcl-xl, gossypol acetate, in multiple myeloma in vitro and in vivo. Oncol Rep 30: 731-738, 2013.

33. Sadahira K, Sagawa M, Nakazato T, Uchida H, Ikeda Y, Okamoto S, Nakajima H and Kizaki M: Gossypol induces apoptosis in multiple myeloma cells by inhibition of interleukin- 6 signaling and Bcl-2/Mcl-1 pathway. Int J Oncol 45: 2278-2286, 2014.

34. Baoleri X, Dong C, Zhou Y, Zhang Z, Lu X, Xie P and Li Y: Combination of L-gossypol and low-concentration doxorubicin induces apoptosis in human synovial sarcoma cells. Mol Med Rep 12: 5924-5932, 2015.

35. Benvenuto M, Mattera R, Masuelli L, Taffera G, Andracchio O, Tresoldi I, Lido P, Giganti MG, Godos J, Modesti A and Bei R: $( \pm)$-Gossypol induces apoptosis and autophagy in head and neck carcinoma cell lines and inhibits the growth of transplanted salivary gland cancer cells in BALB/c mice. Int J Food Sci Nutr 68: 298-312, 2017.

36. Zhao GX, Xu LH, Pan H, Lin QR, Huang MY, Cai JY, Ouyang DY and He XH: The BH3-mimetic gossypol and noncytotoxic doses of valproic acid induce apoptosis by suppressing cyclin-A2/Akt/FOXO3a signaling. Oncotarget 6: 38952-38966, 2015.

37. Zhang M, Liu H, Tian Z, Griffith BN, Ji M and Li QQ: Gossypol induces apoptosis in human PC-3 prostate cancer cells by modulating caspase-dependent and caspase-independent cell death pathways. Life Sci 80: 767-774, 2007.
38. Volate SR, Kawasaki BT, Hurt EM, Milner JA, Kim YS, White J and Farrar WL: Gossypol induces apoptosis by activating p53 in prostate cancer cells and prostate tumor-initiating cells. Mol Cancer Ther 9: 461-470, 2010.

39. Lu MD, Li LY, Li PH, You T, Wang FH, Sun WJ and Zheng ZQ: Gossypol induces cell death by activating apoptosis and autophagy in HT-29 cells. Mol Med Rep 16: 2128-2132, 2017.

40. Jin L, Chen Y, Mu X, Lian Q, Deng Hand Ge R: Phosphoproteomic analysis of gossypol-induced apoptosis in ovarian cancer cell line, HOCla. Biomed Res Int 2014: 123482, 2014.

41. Wang J, Jin L, Li X, Deng H, Chen Y, Lian Q, Ge R and Deng H: Gossypol induces apoptosis in ovarian cancer cells through oxidative stress. Mol Biosyst 9: 1489-1497, 2013.

42. Xin J, Zhan YH, Xia LM, Zhu HW, Nie YZ, Liang JM and Tian J: ApoG2 as the most potent gossypol derivatives inhibits cell growth and induces apoptosis on gastric cancer cells. Biomed Pharmacother 67: 88-95, 2013.

43. Cheng W, Zhao YQ, Li YM and Yang DJ: Effects of gossypol acetate on apoptosis in primary cultured cells from patients with lymphoid leukemia and its synergy with dexamethasone.Zhongguo Shi Yan Xue Ye Xue Za Zhi 20: 229-234, 2012 (In Chinese)

44. Balakrishnan K, Wierda WG, Keating MJ and Gandhi V: Gossypol, a BH3 mimetic, induces apoptosis in chronic lymphocytic leukemia cells. Blood 112: 1971-1980, 2008.

45. Tang J, Wang Z, Chen L, Huang G and Hu X: Gossypol acetate induced apoptosis of pituitary tumor cells by targeting the BCL-2 via the upregulated microRNA miR-15a. Int J Clin Exp Med 8: 9079-9085, 2015

46. Karaca B, Atmaca H, Uzunoglu S, Karabulut B, Sanli UA and Uslu R: Enhancement of taxane-induced cytotoxicity and apoptosis by gossypol in human breast cancer cell line MCF-7. J BUON 14: 479-485, 2009.

47. Yoshida R, Niki M, Jyotaki M, Sanematsu K, Shigemura N and Ninomiya Y: Modulation of sweet responses of taste receptor cells. Semin Cell Dev Biol 24: 226-231, 2013.

48. Tate CR, Rhodes LV, Segar HC, Driver JL, Pounder FN, Burow ME and Collins-Burow BM: Targeting triple-negative breast cancer cells with the histone deacetylase inhibitor panobinostat. Breast Cancer Res 14: R79, 2012.

49. Messeha SS, Zarmouh NO, Mendonca P, Alwagdani H, Kolta MG and Soliman KFA: The inhibitory effects of plumbagin on the NF- $\kappa \mathrm{B}$ pathway and CCL2 release in racially different triple-negative breast cancer cells. PLoS One 13: e0201116, 2018.

50. Citalingam K, Abas F, Lajis NH, Othman I and Naidu R: Anti-proliferative effect and induction of apoptosis in androgen-independent human prostate cancer cells by 1,5-bis(2-hydroxyphenyl)-1,4-pentadiene-3-one. Molecules 20: 3406-3430, 2015

51. Chougule MB, Patel AR, Jackson T and Singh M: Antitumor activity of noscapine in combination with doxorubicin in triple negative breast cancer. PLoS One 6: e17733, 2011.

52. Plati J, Bucur O and Khosravi-Far R: Dysregulation of apoptotic signaling in cancer: Molecular mechanisms and therapeutic opportunities. J Cell Biochem 104: 1124-1149, 2008.

53. Kretschmer C, Sterner-Kock A, Siedentopf F, Schoenegg W, Schlag PM and Kemmner W: Identification of early molecular markers for breast cancer. Mol Cancer 10: 15, 2011.

54. Ma XJ, Salunga R, Tuggle JT, Gaudet J, Enright E, McQuary P, Payette T, Pistone M, Stecker K, Zhang BM, et al: Gene expression profiles of human breast cancer progression. Proc Natl Acad Sci USA 100: 5974-5979, 2003.

55. Van Poznak C, Seidman AD, Reidenberg MM, Moasser MM, Sklarin N, Van Zee K, Borgen P, Gollub M, Bacotti D, Yao TJ, et al: Oral gossypol in the treatment of patients with refractory metastatic breast cancer: A phase I/II clinical trial. Breast Cancer Res Treat 66: 239-248, 2001.

56. Wong RS: Apoptosis in cancer: From pathogenesis to treatment. J Exp Clin Cancer Res 30: 87, 2011.

57. Zhan Q: Gadd45a, a p53- and BRCA1-regulated stress protein, in cellular response to DNA damage. Mutat Res 569: 133-143, 2005

58. Tront JS, Willis A, Huang Y, Hoffman B and Liebermann DA: Gadd45a levels in human breast cancer are hormone receptor dependent. J Transl Med 11: 131, 2013.

59. Desjardins S, Ouellette G, Labrie Y, Simard J; INHERIT BRCAs and Durocher F: Analysis of GADD45A sequence variations in French Canadian families with high risk of breast cancer. J Hum Genet 53: 490-498, 2008.

60. Takekawa $M$ and Saito $H$ : A family of stress-inducible GADD45-like proteins mediate activation of the stress-responsive MTK1/MEKK4 MAPKKK. Cell 95: 521-530, 1998. 
61. Harkin DP, Bean JM, Miklos D, Song YH, Truong VB, Englert C Christians FC, Ellisen LW, Maheswaran S, Oliner JD and Haber DA: Induction of GADD45 and JNK/SAPK-dependent apoptosis following inducible expression of BRCA1. Cell 97: 575-586, 1999.

62. Yasuda M, Theodorakis P, Subramanian T and Chinnadurai G: Adenovirus E1B-19K/BCL-2 interacting protein BNIP3 contains a $\mathrm{BH} 3$ domain and a mitochondrial targeting sequence. J Biol Chem 273: 12415-12421, 1998.

63. Bandyopadhyay S, Zhan R, Wang Y, Pai SK, Hirota S, Hosobe S, Takano Y, Saito K, Furuta E, Iiizumi M, et al: Mechanism of apoptosis induced by the inhibition of fatty acid synthase in breast cancer cells. Cancer Res 66: 5934-5940, 2006.

64. Vande Velde C, Cizeau J, Dubik D, Alimonti J, Brown T, Israels S, Hakem R and Greenberg AH: BNIP3 and genetic control of necrosis-like cell death through the mitochondrial permeability transition pore. Mol Cell Biol 20: 5454-5468, 2000.

65. Khan A, Aljarbou AN, Aldebasi YH, Faisal SM and Khan MA: Resveratrol suppresses the proliferation of breast cancer cells by inhibiting fatty acid synthase signaling pathway. Cancer Epidemiol 38: 765-772, 2014

66. Silva JC, Ferreira-Strixino J, Fontana LC, Paula LM, Raniero L, Martin AA and Canevari RA: Apoptosis-associated genes related to photodynamic therapy in breast carcinomas. Lasers Med Sci 29: 1429-1436, 2014.

67. Ruddle NH: Tumor necrosis factor (TNF-alpha) and lymphotoxin (TNF-beta). Curr Opin Immunol 4: 327-332, 1992.

68. Rath PC and Aggarwal BB: TNF-induced signaling in apoptosis. J Clin Immunol 19: 350-364, 1999.

69. Robbs BK, Lucena PI and Viola JP: The transcription factor NFAT1 induces apoptosis through cooperation with Ras/Raf/MEK/ERK pathway and upregulation of TNF- $\alpha$ expression. Biochim Biophys Acta 1833: 2016-2028, 2013.

70. Balkwill F: TNF-alpha in promotion and progression of cancer Cancer Metastasis Rev 25: 409-416, 2006.

71. Szlosarek PW and Balkwill FR: Tumour necrosis factor alpha: A potential target for the therapy of solid tumours. Lancet Oncol 4: 565-573, 2003

72. Balkwill F: Tumor necrosis factor or tumor promoting factor? Cytokine Growth Factor Rev 13: 135-141, 2002.

73. Luo JL, Maeda S, Hsu LC, Yagita H and Karin M: Inhibition of NF-kappaB in cancer cells converts inflammation-induced tumor growth mediated by TNFalpha to TRAIL-mediated tumor regression. Cancer Cell 6: 297-305, 2004.

74. Hassan M, Watari H, AbuAlmaaty A, Ohba Y and Sakuragi N Apoptosis and molecular targeting therapy in cancer. Biomed Res Int 2014: 150845, 2014

75. Hahne M, Kataoka T, Schröter M, Hofmann K, Irmler M, Bodmer JL, Schneider P, Bornand T, Holler N, French LE, et al: APRIL, a new ligand of the tumor necrosis factor family, stimulates tumor cell growth. J Exp Med 188: 1185-1190, 1998.

76. Schwarz H, Valbracht J, Tuckwell J, von Kempis J and Lotz M: ILA, the human 4-1BB homologue, is inducible in lymphoid and other cell lineages. Blood 85: 1043-1052, 1995.

77. Bellarosa D, Bressan A, Bigioni M, Parlani M, Maggi CA and Binaschi M: SAHA/Vorinostat induces the expression of the CD137 receptor/ligand system and enhances apoptosis mediated by soluble CD137 receptor in a human breast cancer cell line. Int J Oncol 41: 1486-1494, 2012.

78. Hingorani P, Dickman P, Garcia-Filion P, White-Collins A Kolb EA and Azorsa DO: BIRC5 expression is a poor prognostic marker in ewing sarcoma. Pediatr Blood Cancer 60: 35-40, 2013

79. Jha K, Shukla M and Pandey M: Survivin expression and targeting in breast cancer. Surg Oncol 21: 125-131, 2012.

80. Shin S, Sung BJ, Cho YS, Kim HJ, Ha NC, Hwang JI, Chung CW, Jung YK and Oh BH: An anti-apoptotic protein human survivin is a direct inhibitor of caspase-3 and -7. Biochemistry 40 : $1117-1123,2001$.

81. Ghaffari K, Hashemi M, Ebrahimi E and Shirkoohi R: BIRC5 genomic copy number variation in early-onset breast cancer. Iran Biomed J 20: 241-245, 2016.

82. Mahlamäki EH, Bärlund M, Tanner M, Gorunova L, Höglund M, Karhu R and Kallioniemi A: Frequent amplification of 8q24, $11 \mathrm{q}, 17 \mathrm{q}$, and 20q-specific genes in pancreatic cancer. Genes Chromosomes Cancer 35: 353-358, 2002.
83. Baykara O, Bakir B, Buyru N, Kaynak K and Dalay N Amplification of chromosome 8 genes in lung cancer. J Cancer 6 : 270-275, 2015

84. Gunaldi M, Isiksacan N, Kocoglu H, Okuturlar Y, Gunaldi O, Topcu TO and Karabulut M: The value of serum survivin level in early diagnosis of cancer. J Cancer Res Ther 14: 570-573, 2018.

85. Kato J, Kuwabara Y, Mitani M, Shinoda N, Sato A, Toyama T, Mitsui A, Nishiwaki T, Moriyama S, Kudo J and Fujii Y: Expression of survivin in esophageal cancer: Correlation with the prognosis and response to chemotherapy. Int J Cancer 95: 92-95, 2001

86. Coumar MS, Tsai FY, Kanwar JR, Sarvagalla S and Cheung CH: Treat cancers by targeting survivin: Just a dream or future reality? Cancer Treat Rev 39: 802-811, 2013.

87. Gu J, Ren L, Wang X, Qu C and Zhang Y: Expression of livin, survivin, and caspase-3 in prostatic cancer and their clinical significance. Int J Clin Exp Pathol 8: 14034-14039, 2015.

88. Wu B, Yao $\mathrm{H}$, Wang $\mathrm{S}$ and $\mathrm{Xu}$ R: DAPK1 modulates a curcumin-induced $\mathrm{G} 2 / \mathrm{M}$ arrest and apoptosis by regulating STAT3, NF- $\mathrm{BB}$, and caspase-3 activation. Biochem Biophys Res Commun 434: 75-80, 2013

89. Yoo HJ, Byun HJ, Kim BR, Lee KH, Park SY and Rho SB DAPk1 inhibits NF- $\kappa$ B activation through TNF- $\alpha$ and INF- $\gamma$-induced apoptosis. Cell Signal 24: 1471-1477, 2012.

90. Pozniak CD, Radinovic S, Yang A, McKeon F, Kaplan DR and Miller FD: An anti-apoptotic role for the p53 family member, p73, during developmental neuron death. Science 289: 304-306, 2000

91. Melino G, De Laurenzi V and Vousden KH: p73: Friend or foe in tumorigenesis. Nat Rev Cancer 2: 605-615, 2002.

92. Huang L, Li A, Liao G, Yang F, Yang J, Chen X and Jiang X Curcumol triggers apoptosis of p53 mutant triple-negative human breast cancer MDA-MB 231 cells via activation of p73 and PUMA. Oncol Lett 14: 1080-1088, 2017.

93. Yamamoto T, Oda K, Kubota T, Miyazaki K, Takenouti Y, Nimura Y, Hamaguchi $M$ and Matsuda S: Expression of p73 gene, cell proliferation and apoptosis in breast cancer: Immunohistochemical and clinicopathological study. Oncol Rep 9: 729-735, 2002

94. Yu XJ, Fang F and Xie J: Relationship between TP73 polymorphism (G4C14-A4T14) and cancer risk: A meta-analysis based on literatures. Gene 484: 42-46, 2011.

95. Jung JH, Chae YS, Moon JH, Kang BW, Kim JG, Sohn SK, Park JY, Lee MH and Park HY: TNF superfamily gene polymorphism as prognostic factor in early breast cancer. J Cancer Res Clin Oncol 136: 685-694, 2010.

96. Jarvis WD, Turner AJ, Povirk LF, Traylor RS and Grant S: Induction of apoptotic DNA fragmentation and cell death in HL-60 human promyelocytic leukemia cells by pharmacological inhibitors of protein kinase C. Cancer Res 54: 1707-1714, 1994.

97. Wang Y and Rao PN: Effect of gossypol on DNA synthesis and cell cycle progression of mammalian cells in vitro. Cancer Res 44: 35-38, 1984.

98. Kitada S, Leone M, Sareth S, Zhai D, Reed JC and Pellecchia M Discovery, characterization, and structure-activity relationships studies of proapoptotic polyphenols targeting B-cell lymphocyte/leukemia-2 proteins. J Med Chem 46: 4259-4264, 2003.

99. Oliver CL, Miranda MB, Shangary S, Land S, Wang S and Johnson DE: (-)-Gossypol acts directly on the mitochondria to overcome $\mathrm{Bcl}-2$ - and $\mathrm{Bcl}-\mathrm{X}(\mathrm{L})$-mediated apoptosis resistance. Mol Cancer Ther 4: 23-31, 2005.

100. Lei X, Chen Y, Du G, Yu W, Wang X, Qu H, Xia B, He H, Mao J, Zong W, et al: Gossypol induces Bax/Bak-independent activation of apoptosis and cytochrome $c$ release via a conformational change in Bcl-2. FASEB J 20: 2147-2149, 2006.

This work is licensed under a Creative Commons Attribution-NonCommercial-NoDerivatives 4.0 International (CC BY-NC-ND 4.0) License. 